\title{
Algoritma Honey Encryption dalam Sistem Pendataan Sertifikat Tanah dan Bangunan di Universitas Malikussaleh
}

\author{
Sujacka Retno*, Novia Hasdyna ${ }^{* *}$, Mutasar ${ }^{* * *}$, Rozzi Kesuma Dinata**** \\ ${ }^{*, * * * * *}$ Program Studi Teknik Informatika, Universitas Islam Kebangsaan Indonesia \\ ${ }^{* * * *}$ Program Studi Teknik Informatika, Universitas Malikussaleh \\ sujackaretno@gmail.com, ${ }^{* *}$ noviahasdyna@gmail.com, ${ }^{* * *}$ mutasarstmik@gmail.com, ${ }^{* * * *}$ rozzi@unimal.ac.id
}

\begin{abstract}
The management of Land and Building Certificates at Universitas Malikussaleh is still using a manual library in Biro Perlengkapan which contains some problem whereas it can be burned accidentally refers to fire case in 2017 in Rektorat Building at Universitas Malikussaleh. Given the problem faced by the staff in Biro Perlengkapan, the authors idea is to create a database-based data processing system, the authors designed an integrated information system which be able to anticipated such problem in the future and saving time to collecting important certificates such Land and Building Certificates at Universitas Malikussaleh and protecting them with Honey Encryption algorithm. The information system based on desktop and works as a client-server system. The result of this research provide that the honey encryption algorithm can protect the data and it can solve the problem in management system of land and building certificates.
\end{abstract}

Keyword: Honey Encryption, Database, Client-Server, Dekstop

\section{Introduction}

Teknologi Informasi berkembang yang cukup pesat memudahkan pekerjaan manusia dalam melakukan pekerjaan, khususnya dalam mengelola data dan informasi [1]. Perkembangan teknologi informasi ini membawa dampak yang sangat besar dalam pengelolaan data dan penyajian informasi pada suatu instansi pemerintahan ataupun swasta. Sistem Informasi adalah salah satu hasil dari perkembangan teknologi informasi yang berguna untuk meningkatkan kinerja pengolahan data yang akan memberikan informasi yang baik dan akurat [2].

Sistem informasi merupakan sebuah sistem di dalam suatu organisasi yang mampu mengolah berbagai macam kegiatan seperti transaksi harian, mendukung operasi, bersifat manajerial dan kegiatan strategi dari organisasi tersebut dan menyediakan pihak luar tertentu dengan laporan-laporan yang diperlukan [3]. Sistem informasi terdiri dari beberapa komponen yang berupa input, model, ouput, teknologi, hardware, software, basis data, dan komponen kontrol [4]. Pendataan sertifikat dapat dilakukan menggunakan sebuah sistem informasi untuk mengantisipasi berbagai masalah yang terjadi seperti masalah kebakaran, kebanjiran, kemalingan, hingga menyebabkan hilangnya data sertifikat-sertifikat penting pada sebuah instansi pemerintahan ataupun swasta [5].

Saat ini manajemen pengelolaan data sertifikat tanah dan bangunan pada Universitas Malikussaleh masih bersifat manual yang disimpan di dalam lemari brangkas di Biro Perlengkapan Universitas Malikussaleh. Hal ini dapat berdampak buruk mengingat kasus kebakaran yang pernah terjadi pada tahun 2017 di gedung Rektorat Universitas Malikussaleh menyebabkan terbakarnya berkas-berkas penting pada instansi tersebut. Untuk itu, peneliti memberikan solusi untuk membuat sebuah sistem informasi pendataan sertifikat tanah dan bangunan yang bersifat client-server pada universitas tersebut. Penerapan sebuah sistem juga dibutuhkan algoritma kriptografi untuk pengamanan data. Penelitian ini menggunakan algoritma honey encryption. Algoritma Honey Encryption merupakan sebuah algoritma yang dapat dikatakan baru didalam sebuah ilmu kriptografi. Kriptografi yakni salah satu alat komunikasi dan berita kuno yang masih dimanfaatkan sampai dikala ini. Kriptografi di Indonesia disebut persandian merupakan secara singkat bisa berarti seni melindungi data dan berita atai informasi dari pihak yang tidak dikehendaki ketika ditransmisikan ataupun ketika disimpan. Padahal ilmu persandiarmya disebut kriptologi merupakan ilmu yang mempelajari perihal bagaimana tehnik melindungi data dan suatu informasi hal yang demikian beserta semua ikutannya. Algoritma ini dikembangkan oleh seorang peneliti yang bernama Ari Juels, ex-kepala ilmuwan RSA, dan 
temannya Thomas Ristenpart dari University of Wisconsin. Algoritma honey encryption paling cocok digunakan dalam sebuah kondisi dimana data yang terenkrispi diperoleh dari kata sandi [6].

Pada penelitian ini mengimplementasikan sistem informasi pendataan sertifikat tanah dan bangunan berbasis desktop dan bersifat client-server dengan menerapkan algoritma honey encryption untuk pengamanan data yang dapat berfungsi untuk membantu menyelesaikan masalah dan memudahkan dalam pengelolaan informasi terkait sertifikat-sertifikat tanah dan bangunan di Biro Perlengkapan Universitas Malikussaleh.

\section{Research Method}

Pada penelitian ini, metode yang digunakan adalah observasi dan wawancara. Observasi dilakukan dengan meninjau secara langsung ke Biro Perlengkapan Universitas Malikussaleh untuk memperoleh informasi yang dibutuhkan dalam membuat sistem informasi. Proses wawancara dilakukan dengan mewawancarai langsung staff atau pegawai di Biro Perlengkapan terkait dengan informasi sertifikat-sertifikat penting pada Universitas Malikussaleh. Adapun proses penelitian ini berdasarkan langkah-langkah sebagai berikut pada gambar 1 .

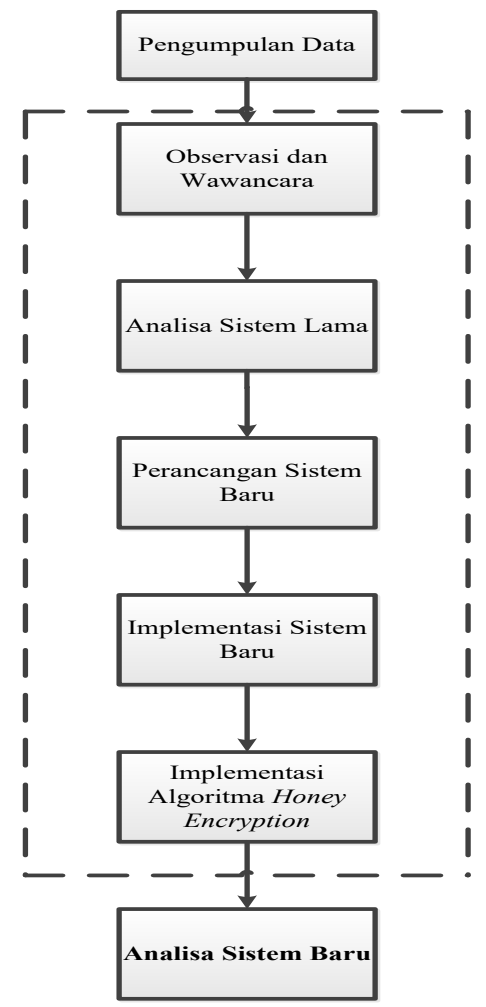

Gambar 1. Langkah-langkah Penelitian

\section{Result and Analysis}

\section{a. Diagram Konteks}

Diagram konteks yang memperlihatkan sebuah proses sistem pendataan sertifikat pada Biro Perlengkapan Universitas Malikussaleh terlihat pada gambar 2 dibawah ini.

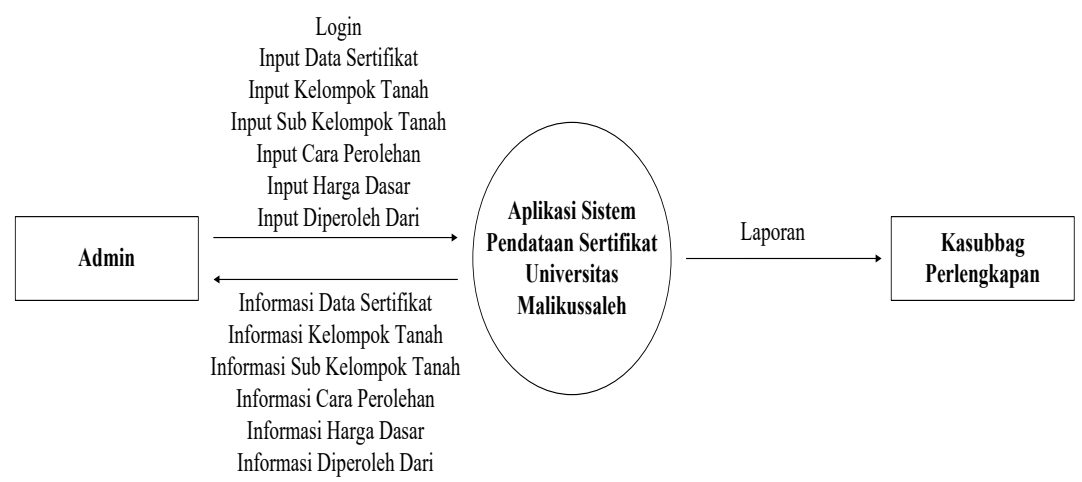

Gambar 2. Diagram Konteks 
Pada diagram ini terdapat 2 entitas yaitu admin dan Kasubbag Perlengkapan. Admin dapat mengelola data sertifikat tanah dan bangunan. Sedangkan entitas Kasubbag Perlengkapan dapat menerima laporan/informasi data sertifikat tanah dan bangunan.

\subsection{Data Flow Diagram (DFD)}

DFD merupakan sebuah diagram yang menggunakan nota dalam menggambarkan alur dari data sistem, dimana hal tersebut sangat membantu untuk memahami sistem secara logika, tersruktur dan jelas. DFD juga sering dikenal dengan istilah lain yaitu Bubble Chart, Bubble diagram, model proses, diagram alur kerja, dan juga model fungsi. DFD adalah sebuah tool dalam membuat model yang akan diterapkan, khususnya bila fungsi-fungsi sistem tersebut adalah sebagian hal yang lebih penting dan rumit dibandingkan dengan data yang akan dimanipulasi oleh sistem. Dapat disimpulkan bahwa DFD adalah tool dalam membentuk sebuah model yang memberi kemudahan dalam sebuah fungsi sistem. DFD dalam kata lain adalah tool persancangan sistem yang berorientasi dalam sebuah alur data dengan sebuah konsep dekomposisi yang dipakai dalam menganalisa ataupun merancang sistem yang dikomunikasikan dengan para professional program tentu dengan laporan-laporan yang diperlukan [7]. Berikut merupakan gambar DFD untuk sistem yang dibangun.

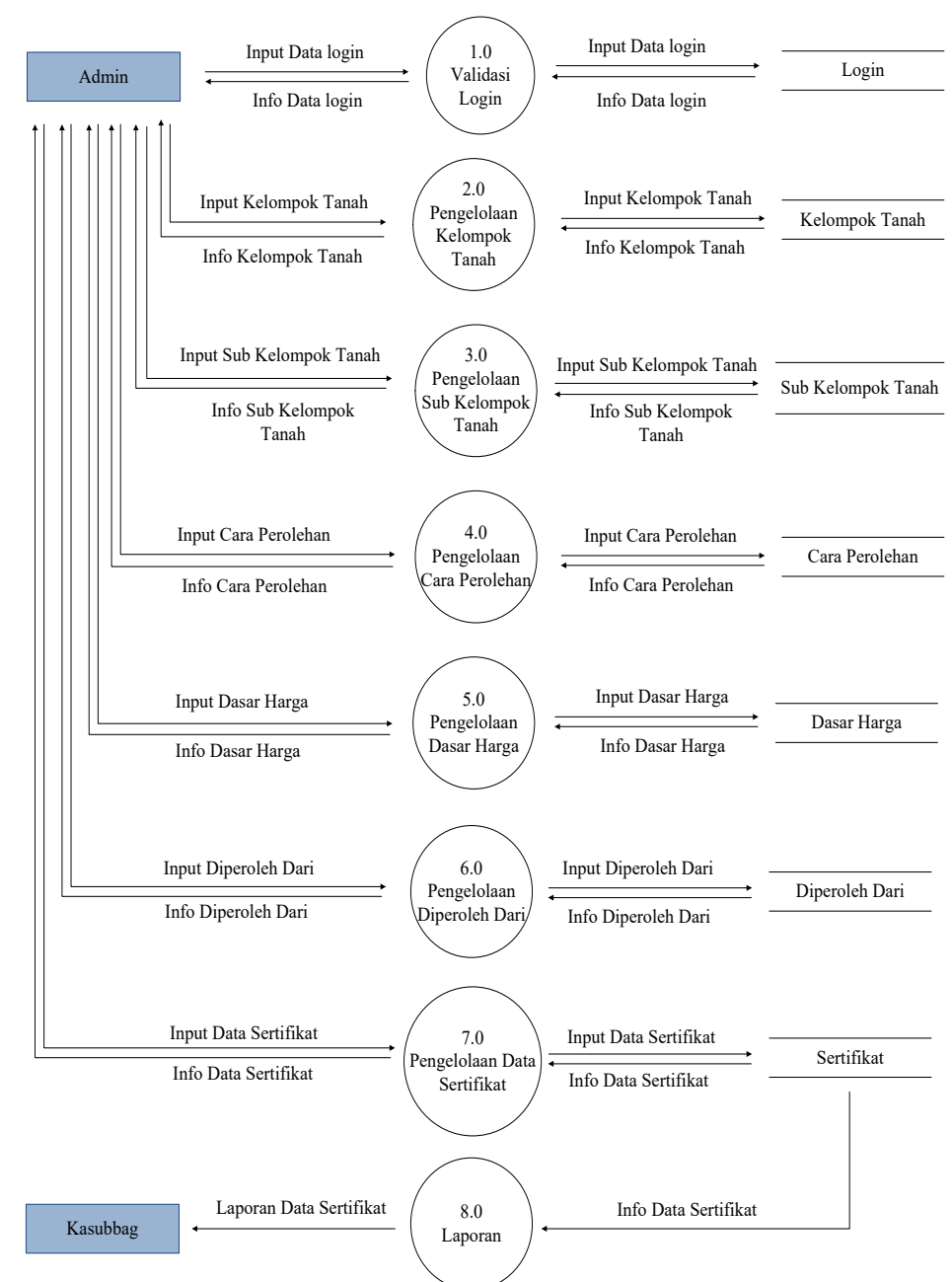

Gambar 3. Data Flow Diagram (DFD)

\subsection{Entity Relationship Diagram (ERD)}

Entity relationship diagram (ERD) adalah sebuah cara yang dilakukan dalam menggambarkan model dari kebutuhan data pada sebuah organisasi. Pada umumnya, seorang System Analyst pada tahapan menganalisa syarat dari projek dalam mengembangkan sistem. Dimana seolah-olah teknik penggambaran tersebut memberikan aspek dasar dalam mendesain relasi yang ada pada database. ERD berkaitan dengan detail pendukung model data yang akan dipakai untuk menspesifikasikan relasi yang ada pada sebuah database [8]. Berikut ini adalah ERD dari sistem yang dibangun : 


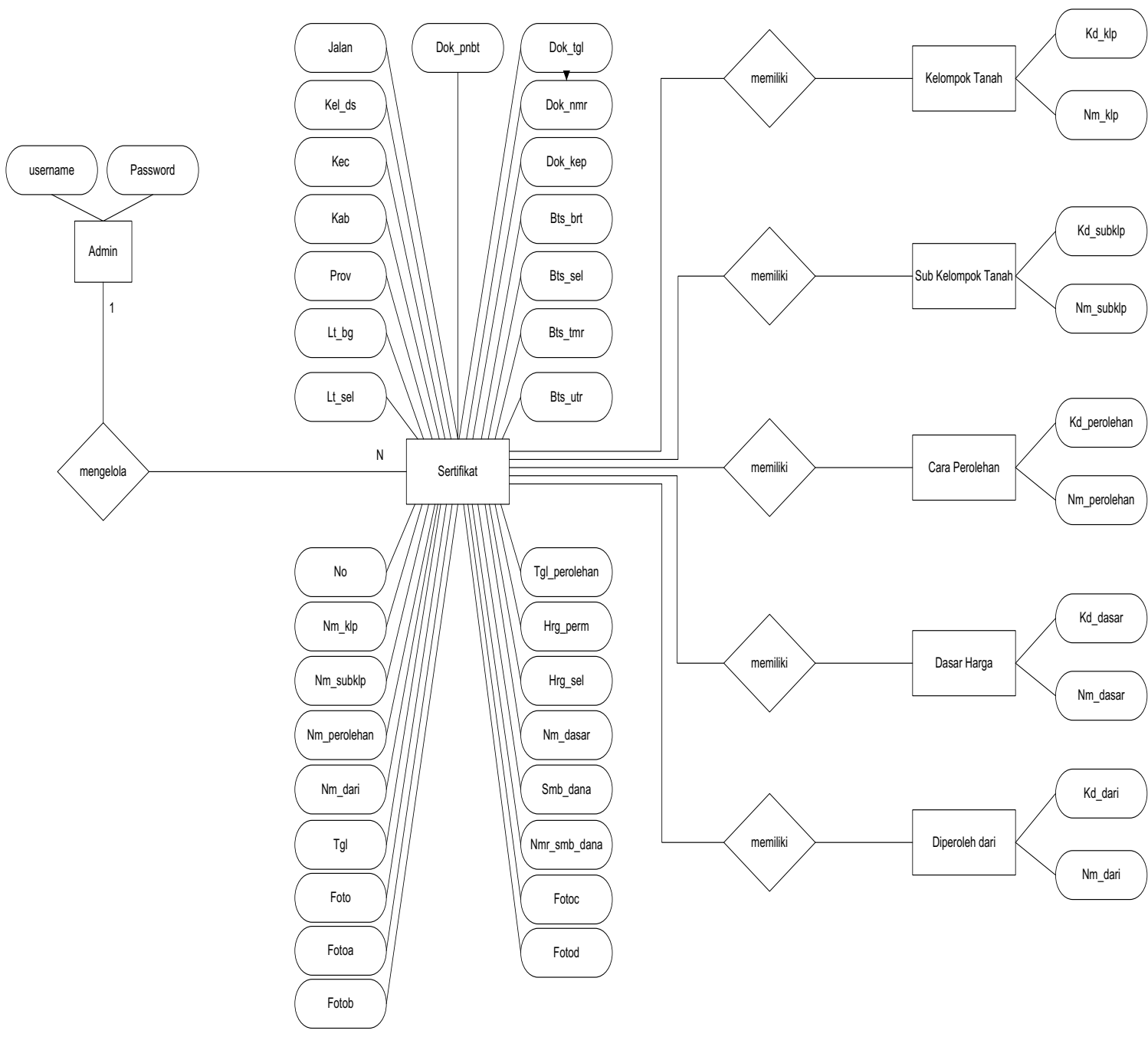

Gambar 4. Entity Relationship Diagram (ERD)

Pada gambar diatas menunjukkan proses Entity Relationship Diagram yang terdiri dari dua entitas, yaitu admin dan kasubbag perlengkapan. Admin dapat mengelola data sertifikat tanah dan bangunan. Sedangkan entitas Kasubbag Perlengkapan dapat menerima laporan/informasi data sertifikat tanah dan bangunan.

\subsection{Struktur Database}

3.3.1. Tabel Login

Struktur data pada tabel Login dapat dilihat pada tabel 1.

Tabel 1. Tabel Login

\begin{tabular}{cllcl}
\hline No & Field Name & Tipe & Char & Keterangan \\
\hline 1 & Username & Text & 25 & Primary Key \\
2 & Password & Text & 25 & \\
\hline
\end{tabular}

\subsubsection{Tabel Kelompok Tanah}

Struktur data pada tabel Kelompok Tanah dapat dilihat pada tabel 2.

Tabel 2. Tabel Kelompok Tanah

\begin{tabular}{cllcl}
\hline No & Field Name & Tipe & Char & Keterangan \\
\hline 1 & Kd_klp & Text & 3 & Primary Key \\
2 & Nm_klp & Text & 100 & \\
\hline
\end{tabular}




\subsubsection{Tabel Sub Kelompok Tanah}

Struktur data pada tabel Sub Kelompok Tanah dapat dilihat pada tabel 3.

Tabel 3. Tabel Sub Kelompok Tanah

\begin{tabular}{cllcl}
\hline No & Field Name & Tipe & Char & Keterangan \\
\hline 1 & Kd_subklp & Text & 3 & Primary Key \\
2 & Nm_subklp & Text & 100 & \\
\hline
\end{tabular}

\subsubsection{Tabel Cara Perolehan}

Struktur data pada tabel Cara Perolehan dapat dilihat pada tabel 4.

Tabel 4. Tabel Cara Perolehan

\begin{tabular}{clccc}
\hline No & Field Name & Tipe & Char & Keterangan \\
\hline 1 & Kd_perolehan & Text & 3 & Primary Key \\
2 & Nm_perolehan & Text & 50 & \\
\hline
\end{tabular}

\subsubsection{Tabel Dasar Harga}

Struktur data pada tabel Dasar Harga dapat dilihat pada tabel 5.

Tabel 5. Tabel Dasar Harga

\begin{tabular}{clccc}
\hline No & Field Name & Tipe & Char & Keterangan \\
\hline 1 & Kd_dasar & Text & 3 & Primary Key \\
2 & Nm dasar & Text & 50 & \\
\hline
\end{tabular}

\subsubsection{Tabel Diperoleh Dari}

Struktur data pada tabel Diperoleh Dari dapat dilihat pada tabel 6.

Tabel 6. Tabel Diperoleh Dari

\begin{tabular}{cllcl}
\hline No & Field Name & Tipe & Char & Keterangan \\
\hline 1 & Kd_dari & Text & 3 & Primary Key \\
2 & Nm_dari & Text & 50 & \\
\hline
\end{tabular}

\subsubsection{Tabel Sertifikat}

Struktur data pada tabel Sertifikat dapat dilihat pada tabel 7.

Tabel 7. Tabel Sertifikat

\begin{tabular}{cllcl}
\hline No & Field Name & Tipe & Char & Keterangan \\
\hline 1 & No & Text & 5 & Primary Key \\
2 & Nm_klp & Text & 100 & Foreign Key \\
3 & Nm_subklp & Text & 100 & Foreign Key \\
4 & Lt_sel & Text & 50 & \\
5 & Lt_bg & Text & 50 & \\
6 & Prov & Text & 50 & \\
7 & Kab & Text & 50 & \\
8 & Kec & Text & 50 & \\
9 & Kel_ds & Text & 50 & \\
10 & Jalan & Text & 50 & \\
11 & Bts_utr & Text & 25 & \\
12 & Bts_tmr & Text & 25 & \\
13 & Bts_sel & Text & 25 & \\
14 & Bts_brt & Text & 25 & \\
15 & Dok_kep & Text & 50 & \\
16 & Dok_nmr & Text & 50 & \\
17 & Dok_tgl & Date/time & & \\
\hline
\end{tabular}




\begin{tabular}{lllll}
\hline 18 & Dok_pnbt & Text & 50 & \\
19 & Nm_perolehan & Text & 50 & Foreign Key \\
20 & Nm_dari & Text & 50 & Foreign Key \\
21 & Tgl_peroleh & Date/time & & \\
22 & Hrg_perm & Text & 25 & \\
23 & Hrg_sel & Text & 25 & \\
24 & Nm_dasar & Text & 50 & Foreign Key \\
25 & Smb_dana & Text & 50 & \\
26 & Nmr_smb_dana & Text & 50 & \\
27 & Tgl & Date/time & & \\
28 & Foto & Text & 255 & \\
29 & Fotoa & Text & 255 & \\
30 & Fotob & Text & 255 & \\
31 & Fotoc & Text & 255 & \\
32 & Fotod & Text & 255 & \\
\hline
\end{tabular}

\subsection{Penerapan Honey Encryption}

Adapun skema proses enkripsi yang digunakan dalam penelitian ini menggunakan algoritma Honey Encryption adalah sebagai berikut :

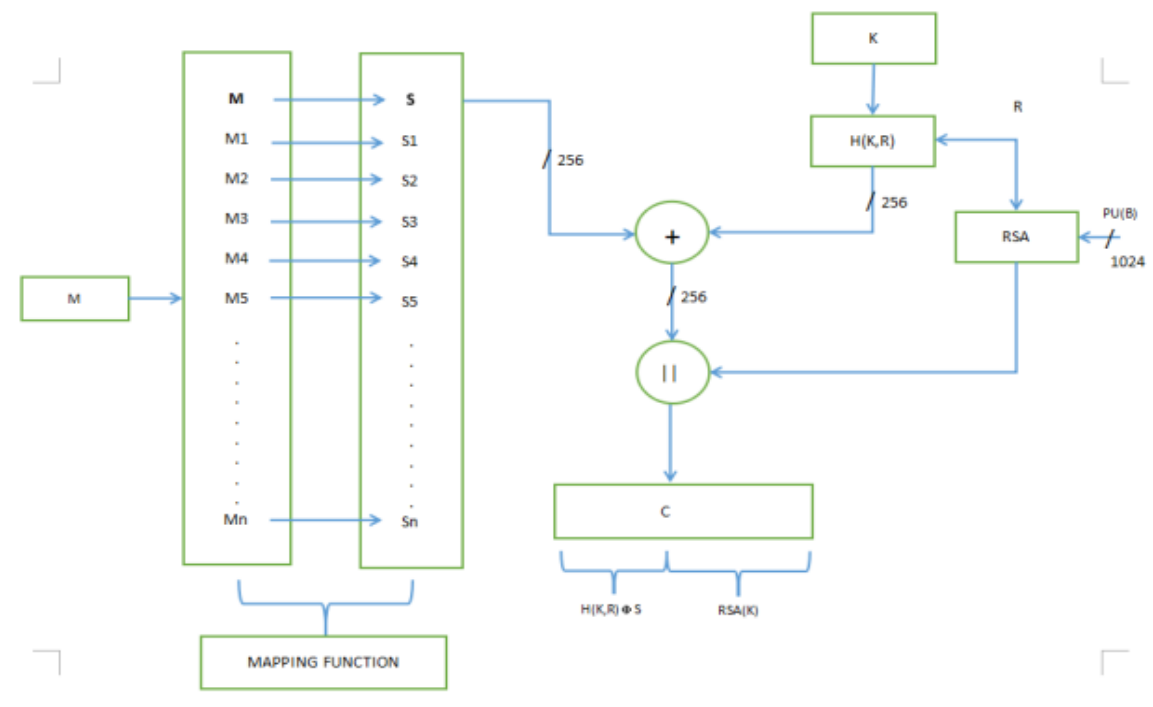

Gambar 5. Skema Proses Enkripsi Algoritma Honey Encryption

Adapun untuk skema proses dekripsi yang digunakan dalam penelitian ini menggunakan algoritma Honey Encryption adalah sebagai berikut :

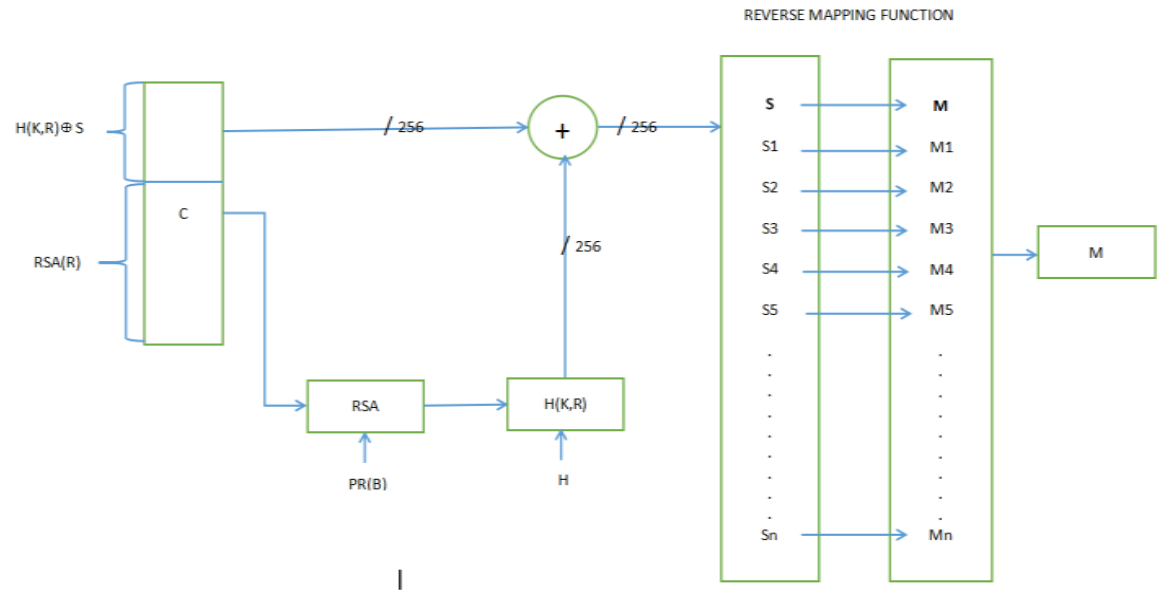

Gambar 6. Skema Proses Dekripsi Algoritma Honey Encryption 
Proses enkripsi dan dekripsi tersebut memiliki ketentuan khusus yang diterapkan kedalam sistem sebagai berikut :

a. Nilai R yang diinput harus berisikan setidaknya 10 karakter yang didalamnya termasuk huruf kapital, huruf kecil dan juga bilangan bulat.

b. Dalam menghitung nilai hash, dilakukan putaran jumlah sebanyak paling sedikit 100000 kali pengulangan.

c. Password yang digunakan tersebut nantinya akan dipakai sebagai nilai kunci $\mathrm{K} 1, \mathrm{~K} 2$, $\mathrm{K} 3$... dimana nantinya akan memudahkan untuk memanipulasi para cryptanalyst.

d. Ketika sender menggunakan key $\mathrm{K}$ yang masih berada diantara pilihan $\mathrm{K} 1, \mathrm{~K} 2$, K3... maka, nilai seed yang didapatkan dari key $\mathrm{K}$ tersebut akan diperbarui dengan nilai $\mathrm{K}$ yang terbaru.

\subsection{Implementasi Sistem}

\subsubsection{Form Login}

Tampilan form login terdapat pada gambar 7 dibawah ini.

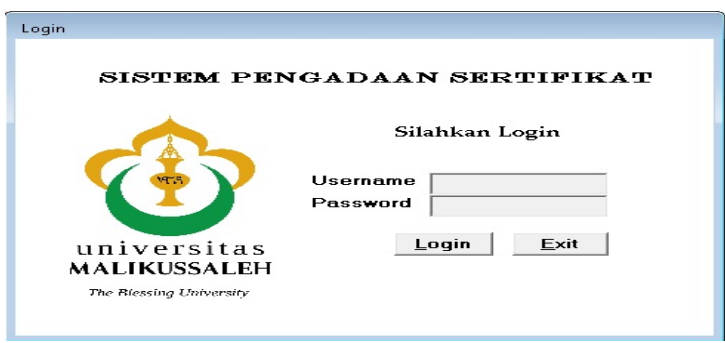

Gambar 7. Form Login

Form ini berfungsi untuk validasi pengguna sistem. Admin cukup memasukkan username dan password, lalu menekan button login. Jika berhasil, setelah diproses terlebih dahulu dengan Honey Encryption, maka sistem akan menampilkan halaman menu utama.

\subsubsection{Form Menu Utama}

Tampilan form menu utama terdapat pada gambar 8 dibawah ini.

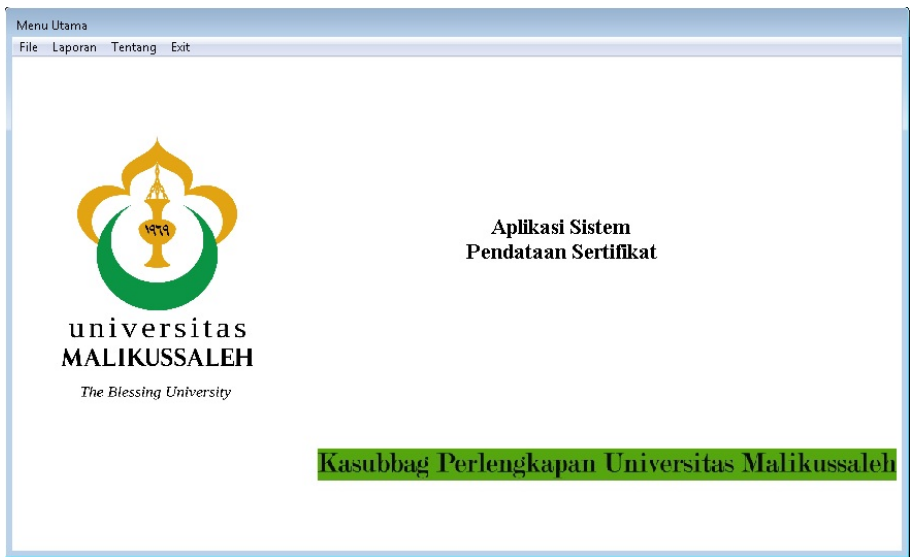

Gambar 8. Form Menu Utama

Menu utama adalah form yang dituju setelah petugas berhasil login kedalam sistem. Halaman ini berisi menu atau pilihan dari sistem informasi.

\subsubsection{Form Sertifikat}

Tampilan form sertifikat terdapat pada gambar 9 berikut ini. 


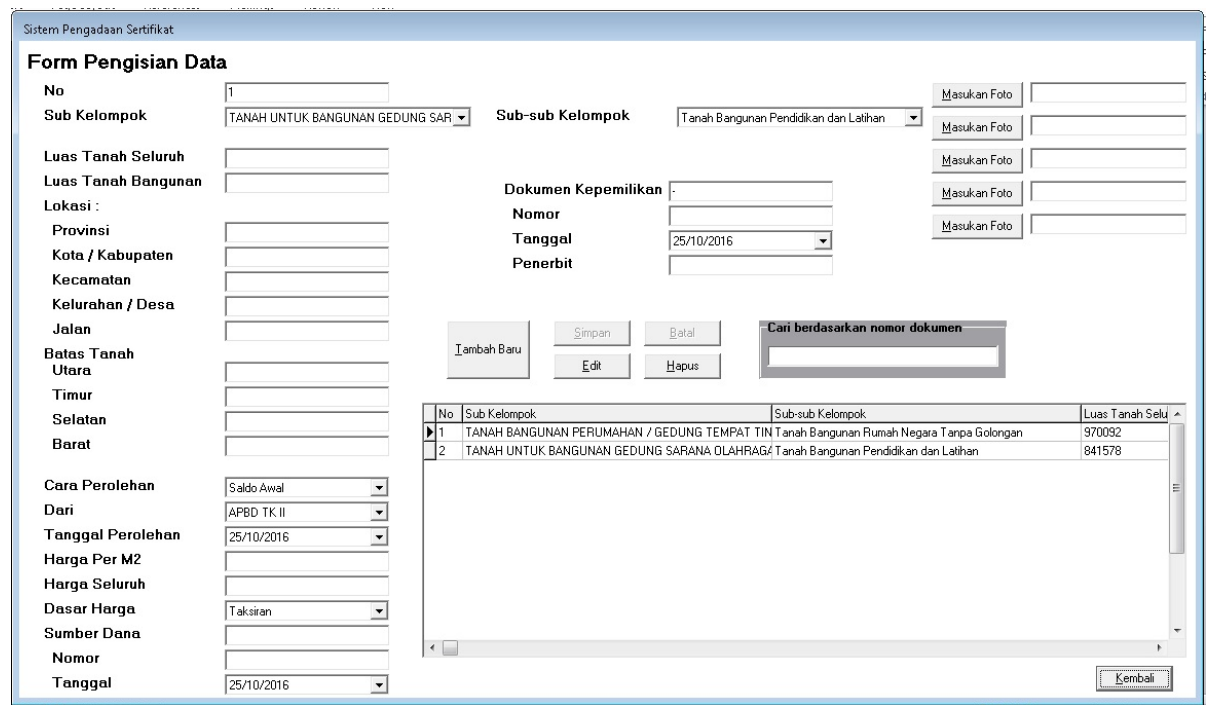

Gambar 9. Form Sertifikat

Form ini berisikan data sertifikat yang ada di Universitas Malikussaleh. Form ini terdiri dari beberapa field yang sudah terelasi dengan form-form sebelumnya dan juga field lainnya seperti nomor dokumen dan sebagainya. Pada halaman ini petugas dapat menginput data sertifikat tersebut atau mengedit data yang sudah ada dan juga dapat menghapus data yang sudah ada apabila terjadi kesalahan. Pada halaman ini juga algoritma Honey Encryption diterapkan sehingga data sertifikat yang disimpan akan diproteksi keamanannya.

\section{Conclusion}

Dari penelitian yang dilakukan di Biro Perlengkapan Universitas Malikussaleh, dapat diambil kesimpulan sebagai berikut :

a. Sistem ini diproteksi dengan algoritma kriptografi Honey Encryption yang mampu menjaga kemanana data yang disimpan dari para cryptanalyst.

b. Sistem ini mampu menyajikan informasi secara tepat, cepat, dan akurat.

c. Tata letak dan tata bangun sistem dan bentuk output pada sistem ini diatur sedemikian rupa sehingga mudah dimengerti, mudah dibaca, dan dapat dilihat isinya dengan cepat oleh admin.

d. Sistem ini mampu menyajikan laporan yang fleksibel sesuai kebutuhan dengan menawarkan 2 jenis laporan yang berbeda didalamnya, laporan detail dan laporan secara keseluruhan sertifikat tersebut.

e. Sistem Informasi Pendataan Sertifikat Tanah dan Bangunan ini merupakan aplikasi client-server yang berbasis desktop, sehingga dapat diakses diseluruh ruang lingkup Biro Perlengkapan Universitas Malikussaleh.

\section{References}

[1] M. Megawati, A. Andi, G. Dian, "Membangun Sistem Informasi Monitoring Kegiatan Proyek Pemancar Sinyal BTS Berbasis Web Pada PT. Swatama Mega Teknik," Jurnal Ilmiah Fifo vol 10, no.1, pp. 22-28, 2018.

[2] M. Mutasar, N. Hasdyna, A. Arafat, "Implementasi Sistem Informasi Monitoring Kendaraan Dinas Terintegrasi Pada Bank Indonesia Lhokseumawe," INFORMAL: Informatics Journal, vol.5, no.2, pp.65-71, 2020

[3] H. Hendri, J. W. H. Manurung, R. A. Ferian, W. F. Hanaatmoko, Y. Yulianti, "Pengujian Black Box pada Aplikasi Sistem Informasi Pengelolaan Masjid Menggunakan Teknik Equivalence Partitions". Jurnal Teknologi Sistem Informasi dan Aplikasi, 3(2), 107-113. 2020

[4] R. K. Dinata, "Sistem Informasi Pendataan Mahasiswa Kerja Praktek di Bank BRI Unit Cot Girek Kanca Lhokseumawe," INFORMAL: Informatics Journal vol 1, no.3, pp. 132-136, 2016.

[5] S. Hidayatullah, U. Khouroh, I. Windhyastiti, R. G. Patalo, A. Waris, "Implementasi Model Kesuksesan Sistem Informasi DeLone And McLean Terhadap Sistem Pembelajaran Berbasis Aplikasi Zoom Di Saat Pandemi Covid19. Jurnal Teknologi Dan Manajemen Informatika, 6(1), 44-52. 2020

[6] S. Retno, N. Hasdyna, "Analisis Kinerja Algoritma Honey Encryption dan Algoritma Blowfish Pada Proses Enkripsi Dan Dekripsi”. TECHSI-Jurnal Teknik Informatika, 10(2), 82-88. 2018.

[7] S. Andrianto, H. Wijoyo, "Rancang Bangun Sistem Informasi Siswa Berbasis Web di Sekolah Minggu Buddha Vihara Dharmaloka Pekanbaru”. TIN: Terapan Informatika Nusantara, 1(2), 83-90. 2020. 
[8] S. Uviyanti, B. A. Pramuka, "Pengaruh Sistem Informasi Akuntansi Terhadap Kualitas Laporan Bantuan Operasional Sekolah (Bos)”. Syntax Literate; Jurnal Ilmiah Indonesia, 5(7), 471-480. 2020. 